\title{
Moral Property Rights in Bargaining with Infeasible Claims
}

Citation for published version (APA):

Riedl, A. M., \& Gächter, S. (2005). Moral Property Rights in Bargaining with Infeasible Claims. Management Science, 51(2), 249-263. https://doi.org/10.1287/mnsc.1040.0311

Document status and date:

Published: 01/01/2005

DOI:

10.1287/mnsc. 1040.0311

Document Version:

Publisher's PDF, also known as Version of record

Document license:

Taverne

Please check the document version of this publication:

- A submitted manuscript is the version of the article upon submission and before peer-review. There can be important differences between the submitted version and the official published version of record.

People interested in the research are advised to contact the author for the final version of the publication, or visit the DOI to the publisher's website.

- The final author version and the galley proof are versions of the publication after peer review.

- The final published version features the final layout of the paper including the volume, issue and page numbers.

Link to publication

\footnotetext{
General rights rights.

- You may freely distribute the URL identifying the publication in the public portal. please follow below link for the End User Agreement:

www.umlib.nl/taverne-license

Take down policy

If you believe that this document breaches copyright please contact us at:

repository@maastrichtuniversity.nl

providing details and we will investigate your claim.
}

Copyright and moral rights for the publications made accessible in the public portal are retained by the authors and/or other copyright owners and it is a condition of accessing publications that users recognise and abide by the legal requirements associated with these

- Users may download and print one copy of any publication from the public portal for the purpose of private study or research.

- You may not further distribute the material or use it for any profit-making activity or commercial gain

If the publication is distributed under the terms of Article $25 \mathrm{fa}$ of the Dutch Copyright Act, indicated by the "Taverne" license above, 


\title{
Moral Property Rights in Bargaining with Infeasible Claims
}

\author{
Simon Gächter \\ CESifo, IZA, and School of Economics, University of Nottingham, University Park, Nottingham NG7 2RD, United Kingdom, \\ simon.gaechter@nottingham.ac.uk \\ Arno Riedl \\ IZA, Tinbergen Institute, and University of Amsterdam, CREED, Faculty of Economics and Econometrics, \\ Roetersstraat 11, NL-1018 WB Amsterdam, The Netherlands, a.m.riedl@uva.nl
}

\begin{abstract}
Tn many business transactions, labor-management relations, international conflicts, and welfare-state reforms, 1 bargainers hold strong entitlements that are often generated by claims that are not feasible anymore. These entitlements seem to shape negotiation behavior considerably. By using the novel setup of a "bargaining with claims" experiment, we provide new systematic evidence tracking the influence of entitlements and obligations through the whole bargaining process. We find strong entitlement effects that shape opening offers, bargaining duration, concessions, and (dis)agreements. We argue that entitlements constitute a "moral property right" that is influential independent of negotiators' legal property rights.
\end{abstract}

Key words: moral property rights; entitlements; fairness judgments; bargaining with claims; self-serving bias; experiment

History: Accepted by John W. Boudreau, organizational behavior, performance, strategy, and design; received February 27, 2004. This paper was with the authors 18 days for 1 revision.

\section{Introduction}

In many negotiations, bargainers bring strong entitlements to the bargaining table. These entitlements are often rooted in historical claims, custom, or the status quo (see, e.g., Kahneman et al. 1986, Zajac 1995). Entitlements seem to matter in business relations, in wage arbitration, wage setting, corporate mergers, nuptial breakups, peace treaties, and many other situations where people need to bargain. ${ }^{1}$

However, in many of these negotiations entitlements are inconsistent. The long-lasting IsraeliPalestinian conflict is a prominent example where infeasible claims-in this case on pieces of landshape entitlements (e.g., Feith 1993). There is also evidence that the welfare state has generated important entitlements of different groups that under changed economic conditions may be inconsistent, but determine attitudes on necessary reforms (e.g., Romer

\footnotetext{
${ }^{1}$ The importance of entitlements extends beyond these examples. In the context of market transactions, Kahneman et al. (1986) were among the first to note the relevance of historical transactions for setting a reference point in what they call the "principle of dual entitlement, which governs community standards of fairness: Transactors have an entitlement to the terms of the reference transaction, and firms are entitled to their reference profit" (italics in original). Kachelmeier et al. (1991) and Franciosi et al. (1995) dwelt on this idea and examined the consequences of entitlements in multiperiod posted-bid and posted-offer market experiments with taxation.
}

1996, Boeri et al. 2001). Inconsistent entitlements that are often based on infeasible claims also seem to influence wage negotiations in companies under economic strain.

To our knowledge there is not yet any systematic investigation on how infeasible claims actually influence entitlements and negotiations. In this paper we take up this issue and provide comprehensive evidence on the influence of infeasible claims on negotiations. We do this by way of controlled laboratory experiments investigating a bargaining problem with infeasible claims and the derived entitlements. For the purposes of our paper, Schlicht (1998, p. 24) provides a very succinct definition of an entitlement, and its counterpart, an obligation:

Entitlements are rights, as perceived by the individual. They are not, however, abstract legal rights. Rather they denote the subjectively perceived rights that go along with a motivational disposition to defend them. Obligations are the counterparts of entitlements. They refer to claims of others that are subjectively accepted, and go along with a motivational disposition to respect these claims (italics added).

To study the role of entitlements in negotiations, we introduce an experimental two-person "bargaining with infeasible claims" setup. It is inspired by the class of "bargaining problems with claims" mainly studied in game theory. A bargaining problem with 
claims is a standard bargaining problem enriched with a "claims point," i.e., a claim on a certain share of the pie that lies outside the feasible bargaining set (see O'Neill 1982 for the seminal paper on such problems).

Chun and Thomson (1992, p. 20) characterize the meaning of claims by an example of a labormanagement negotiation:

...labor and management come to the negotiation table with certain expectations, or with certain claims. ...the claims may represent commitments made to the agents in earlier negotiations which, because of changes in the industry that may have adversely affected the feasible set of the firm, cannot all be honored any more.

A recent prominent example for the relevance of entitlements in bargaining in the business arena are the wage-cut negotiations between United Airlines and the unions representing its employees in Fall 2002 and Spring 2003. These negotiations were necessary because of the threat of bankruptcy United Airlines was facing at this time. They led to (temporary) wage cuts that were quite different for different groups of employees. It ranged from $29 \%$ for the high-salary pilots to $9 \%$ for the relatively low-paid flight attendants (Corfman and Schmeltzer 2002).

In our experiment, we model the bargaining problem with claims as follows. Subjects first acquire claims in a competitive task. With a certain probability, these claims are actually paid out to the subjects. With the remaining probability, the acquired claims are not feasible anymore and subjects have to negotiate an agreement in a completely symmetric free-form bargaining over a computer net. In case they fail to reach an agreement, they earn nothing.

In this research we are interested in the entitlements people derive from infeasible claims and how these entitlements influence negotiations. The claims are the granted shares of the pie, in case the claims are feasible. By contrast, in line with Schlicht's definition, we refer to entitlements as the subjective judgments of bargainers about what their fair share of the remaining pie is, in case the claims are infeasible. To learn about the entitlements bargainers derive from the infeasible claims, negotiators are asked in private what they think a fair settlement from the vantage point of a neutral arbitrator is, before they start to bargain.

This research design allows us to study several important issues. First, we can investigate which entitlements bargainers actually derive from the infeasible claims. Previous research suggests that entitlements are likely to be self-servingly biased (e.g., Babcock and Loewenstein 1997). Second, because entitlements are subjectively held fairness judgments, which may be self-servingly biased, it is likely that they cannot be satisfied without some curtailment by at least one bargaining party. Our experimental design allows us to track the impact of entitlements through the whole negotiation process-from the opening offers, the concessions, and bargaining duration to the reached agreements and disagreements.

Our main results are as follows. First, entitlements as measured by elicited fairness judgments are highly correlated with the claim earned in the first part of the experiment. Quite surprisingly-and in contrast to previous literature-fairness judgments are only modestly self-servingly biased. Second, we show that entitlements influence the whole bargaining process: We find that (i) opening offers are strongly correlated with the entitlements and obligations; (ii) tensions in entitlements held by the negotiators tend to prolong negotiations and are a significant reason for the oftenobserved "deadline effect" of last-minute agreements; (iii) entitlements shape the concessions that are necessary to strike an agreement; and (iv) reached agreements are highly correlated with the entitlements and obligations.

Our result that the agreements are strongly skewed away from the equal division is in stark contrast to previous symmetric free-form bargaining experiments without claims. There, almost unanimously, the equal split was implemented (see, e.g., Nydegger and Owen 1975).

Theoretically, the free-form bargaining game with claims exhibits many possible outcomes. Axiomatic analyses provide arguments for several solutions, each giving different outcomes for the same claims (see Thomson 2003 for an overview). When viewing (the last few seconds of) the free-form bargaining as a Nash-demand game, every efficient allocation of the surplus can be sustained by a noncooperative Nash equilibrium. Because there are many equilibrium outcomes, many variables can provide a correlation device that promotes agreements and influences how the surplus is shared. Our study is the first to show that entitlements derived from infeasible claims are an effective device that strongly and systematically influences the whole negotiation process. Our findings suggest that entitlements constitute a moral property right that exists independently of the legal property rights.

\section{Experimental Setup}

The main purpose of our study is to investigate how entitlements derived from infeasible claims shape negotiations. Therefore, our experimental design consists of three ingredients: (i) negotiations in a "bargaining with claims" experiment, (ii) the implementation of claims, and (iii) the measurement of entitlements. A sample copy of the instructions is available at http://www1.fee.uva.nl/creed/pdffiles / InstrToMPRBIC.pdf. 


\subsection{Features of the Experimental Design}

The "Bargaining with Claims" Environment. At the beginning of the experiment, subjects were randomly and anonymously paired and introduced to the bargaining problem. To make the experimental task cognitively easy and to enhance the perceived symmetry of bargaining roles, we cast the bargaining as one between two "heads of departments" in a hypothetical firm that consists of two departments. Subjects were told that in this firm the total budget available for both salaries is 2,490 "points." In the experiments, 10 points were worth $€ 0.18$. Hence, the salary budget was worth $€ 18.10(\approx \$ 18.00)$. The instructions said that the firm's previous policy always has been to grant the better-performing head of department a higher share of the total salary budget $(1,660$ points) than the lower-performing head of department (830 points). However, there is now the possibility that-due to exogenous factors beyond the control of the firm-economic conditions for the firm become worse and the salary budget will have to be cut to 2,050 points. The firm states that, should this case materialize, it will not impose any sharing of the new salary budget onto the managers. Instead, the firm asks the heads of departments to bargain among themselves to reach an agreement of how to split the new salary budget. If they reach an agreement, it is implemented and each head of department will receive the agreed share. The subjects were also told that they are "fired;" i.e., they will not earn any money in the experiment except the promised show-up fee, should they fail to reach an agreement.

In case the salary budget does not shrink, the bargaining partners are paid according to the previous wage policy: The manager with the better performance will receive a salary of 1,660 points, whereas the manager with the inferior performance will receive a salary of 830 points. Whether the salary budget is 2,490 or 2,050 is determined by chance.

Notice that this story-in the case where the salary budget shrinks-depicts a "bargaining with infeasible claims" problem. In the case where the smaller salary budget becomes relevant, the sum of both "claims" (read "historically implemented sharing of the salary budget") lies outside the bargaining set. The disagreement payoff of the bargaining problem is $(0,0)$.

The Implementation of Claims. In the experiments we explained the "performance measurement" as follows:

In this experiment performance will be measured with a general knowledge quiz. The department head who gives correct answers to a greater number of questions than the other department head has shown the better performance, and has therefore, given the firm's previous policy, earned a salary claim of 1,660 points.
The department head with the lower performance previously received a salary of 830 points.

The "general knowledge quiz" consisted of 16 questions from a variety of fields, including astronomy, history, sports, music, politics, etc. We were very careful to select questions that students with a high school degree should in principle be able to answer, and that subjects would recognize as testing their high school knowledge. The knowledge quiz was a multiple-choice test with five possible choices and only one correct answer. All subjects had to answer the same questions. They had eight minutes to answer the questions.

After the quiz, we told the subjects which of the two bargaining partners did better in the knowledge quiz. We informed them only about the rank of their performance and not about the actual number of correct answers. Apart from simplicity reasons, we wanted to hold the claims constant across subjects and between bargaining pairs.

Recall from the description of our bargaining problem that a chance move determined whether the salary budget shrank to 2,050 points or stayed at 2,490 points, where the latter outcome implied that the claims according to the knowledge quiz were actually paid out. In the experiment the chance move was implemented as follows. After subjects were informed about the rank of their performance, each bargaining partner in a dyad had to roll a six-sided die. It was explained that the claims would actually be paid out if the sum of the numbers of both dice was greater than or equal to 11 . If the sum of the dice numbers was smaller than 11, the bargaining partners had to bargain over how to split the new salary budget of 2,050 points.

The reason we implemented this chance procedure was to make the claims a potential payment in the experiment. This gave the subjects an incentive to see the knowledge quiz as an important part of the experiment. On the other hand, our main research interest is to investigate the impact of perceived entitlements on bargaining outcomes. Therefore, we set the probability that bargaining actually had to take place to $11 / 12$.

Measurement of Entitlements. All subjects in the experiment had to answer the following question (adapted from Babcock et al. 1995):

According to your opinion, what would-in case of the bad economic condition for the firm-be a "fair" distribution of the salaries from the vantage point of a noninvolved neutral arbitrator? (Please use exact amounts; no intervals! The amounts have to sum up to 2050 points!) (emphasis in original.)

In the remainder we will refer to this question as the "arbitrator question." The fairness judgments we 
receive as answers to this arbitrator question inform us on the perceived entitlements and obligations of our subjects. In the results part of the paper, we will link the fairness judgments to the negotiation behavior.

\subsection{Experimental Procedures}

Table 1 summarizes the sequence of events. After subjects arrived at the lab, we randomly allocated them to computer booths, which were located in two different rooms. Each subject's bargaining partner was always in the other room. Subjects first read the experimental instructions that introduced them to the bargaining problem and the performance measurement. After subjects had finished reading the instructions, they answered the knowledge quiz and rolled the dice in front of an experimenter to determine whether the claims would be paid out or whether they would have to bargain over 2,050 points. In case the dice determined that the claims would be paid out, we told the pairs to bargain hypothetically over the sharing of 2,050 points. We ensured the subjects that they would receive their claims irrespective of the outcome in the hypothetical bargaining. (Actually, only one pair had to bargain hypothetically.) We announced the arbitrator question just before the start of the negotiations. We told the subjects that no other participant of the experiment would be informed about their answer to this arbitrator question.

The bargaining was free-form; i.e., there was no fixed bargaining protocol (see, e.g., Roth and Murnighan 1982). Bargaining was conducted over a local area network with the help of the experimental software "Rabbit" (Brandel 1998). The negotiators were allowed to make any (nonnegative) proposal as long as the sum of shares was smaller than or equal to 2,050 points. Subjects also had the opportunity to send messages along with a proposal (as long as these messages did not contain threats or reveal the identity of the sender, which was checked by an experimenter). Mere messages without a proposal were not possible. The negotiators had 15 minutes to reach an

\begin{tabular}{|c|c|}
\hline le 1 & Sequence of Events \\
\hline 1. & Reading of instructions \\
\hline 2. & $\begin{array}{l}\text { Quiz determines claims and subjects are } \\
\text { informed about them } \\
\left(\begin{array}{c}1,660 \text { points for "winner" } \\
830 \text { points for "loser" }\end{array}\right)\end{array}$ \\
\hline 3. & $\begin{array}{l}\text { Nature determines whether claims are paid } \\
\text { out or if bargaining over 2,050 points } \\
\text { takes place }\end{array}$ \\
\hline 4. & Arbitrator question \\
\hline 5. & $\begin{array}{l}\text { Free-form bargaining over } 2,050 \text { points } \\
\quad(\max .900 \mathrm{sec} .)\end{array}$ \\
\hline 6. & Postexperimental questionnaire \\
\hline \# of pairs & 45 \\
\hline
\end{tabular}

agreement. In case of an impasse, subjects earned nothing except their show-up fee. Hence, the "threat point" in this experiment was $(0,0)$. Random pairing, anonymity, duration, and disagreement payoffs were common knowledge.

One reason for choosing free-form bargaining with a symmetric threat point was that it made the bargaining partners strategically equal. By avoiding obvious "first (or last) mover advantages" as well as any other exogenously induced strategic differences, the potential that strategic effects confound possible entitlement effects was minimized. ${ }^{2}$ In addition, compared to a strict bargaining protocol, free-form bargaining gives more freedom to the negotiators, e.g., in the timing and the number of offers. This makes it easier to observe potential entitlement-specific behavioral patterns during the bargaining process.

After the bargaining, we administered a questionnaire that asked the subjects a couple of questions about their socioeconomic characteristics, their motives in the experiment, and their attitudes towards the quiz and the claims.

We conducted the experiments in the computerized lab of the Institute for Advanced Studies in Vienna. Ninety subjects participated in eight experimental sessions. Our subjects were first-year undergraduate students of law, business administration, and computer science. Each session lasted approximately 75 minutes. The average earnings (including a show-up fee of $€ 5.10)$ per subject was approximately $€ 12.50(\approx \$ 12.30)$.

\section{Results}

We will first set the stage by presenting the results of the fairness judgments according to the arbitrator question. Then we will move on to the bargaining process (opening offers, bargaining duration, and concessions) and the agreements and disagreements as a function of the entitlements.

For convenience, we will in the remainder of the paper refer to the subject with the claim of 1,660 (830) as the "winner" ("loser") of the performance quiz. Moreover, we will adopt the convention of expressing all allocations in "winner shares," i.e., the share of the total pie of 2,050 that goes to the "winner" of the quiz, regardless of whether this proposed allocation was made by a winner or a loser.

\subsection{The Entitlements}

There are at least three perspectives that might shape entitlements. First, normative bargaining theory suggests many solutions for our bargaining problem with claims (see Thomson 2003). For instance, the solution

\footnotetext{
${ }^{2}$ For a study that looks at a situation where one party is in a stronger position than the other, see, e.g., Zwick and Chen (1999).
} 
concept "constrained equal award" proposes that the loser receives her whole claim and the winner has to bear the whole reduction of the pie. Another proposed solution is the "constrained equal loss," where the loser bears a disproportionately large share of the reduction of the pie. According to the "proportional rule," which is, for instance, predicted by the "accountability principle" (Konow 2000), the winner is entitled to a share of $2 / 3$. According to the Talmud solution, the winner would be entitled to $60.7 \%$ and the loser to $39.3 \%{ }^{3}$ If negotiators perceive the claims as irrelevant, the "equal split" would result. ${ }^{4}$

Second, entitlements can also be role specific. Winners and losers may arrive at different fairness judgments; i.e., their perceptions are self-servingly biased. For example, it is well known from psychological research that people tend to attribute their success to their skill, but believe that failures are largely due to bad luck (see Zuckerman 1979). Likewise, a large literature indicates that people tend to view as fair what benefits them. ${ }^{5}$

Third, from research in cognitive psychology it is well known that people can entertain multiple representations of the same fact. One representation of entitlements could be that they refer to the historical claims, expressed in nominal terms. This is a possibility because many people suffer from money illusion also in the context of justice evaluations (Kahneman et al. 1986, Shafir et al. 1997). Another representation of entitlements might be that people employ proportionality or some other normative rule to the new budget set and recalculate their entitlements for the lower budget. Both representations are consistent with our view of entitlements because we see entitlements as subjectively perceived rights. These rights might focus on proportionality or any other normative rule, or on the historical claims.

Thus, there are many competing hypotheses about people's perceived entitlements. Our first main result records the evidence.

Result 1. We find clear evidence for asymmetric entitlements, with the proportional split according to the infeasible claims being the empirically

\footnotetext{
${ }^{3}$ The Talmud rule (see, e.g., Aumann and Maschler 1985) is based on the idea that first the portions that are not under dispute are allocated. That is, the winner does not claim more than 1,660 (out of the 2,050), and the loser does not claim more than 830 (out of $2,050)$. Hence, the winner concedes 390 to the loser, whereas the loser concedes 1,220 to the winner. The remaining amount $(2,050-$ $390-1,220=50)$ is split equally. Therefore, the final allocation to the winner is $1,220+25=1,245$, which is $60.7 \%$ of the feasible pie.

${ }^{4}$ For an extensive recent survey on a positive analysis of various justice theories, see Konow (2003).

${ }^{5}$ Evidence for such a self-serving bias has been produced in tightly controlled laboratory experiments (Babcock and Loewenstein 1997, Camerer and Loewenstein 1993), but also in field studies (Babcock et al. 1996) and in survey studies (Dahl and Ransom 1999).
}

Table 2 Summary Statistics of Fairness Judgments

\begin{tabular}{|c|c|c|c|}
\hline & \multicolumn{3}{|c|}{ Arbitrator question } \\
\hline Definition & \multicolumn{3}{|c|}{$\begin{array}{l}\text { "According to your opinion, what would be } \\
\text { a 'fair' distribution of salaries from the } \\
\text { vantage point of a noninvolved neutral } \\
\text { arbitrator?" }\end{array}$} \\
\hline Variable & \multicolumn{3}{|c|}{ Fair distribution (in "winner share") } \\
\hline \multirow[t]{7}{*}{ Admissible range } & $0 \%$ to 100 & & \\
\hline & & \multicolumn{2}{|c|}{$N=90$} \\
\hline & & Mean & Std. dev. \\
\hline & Winner & 64.0 & 6.21 \\
\hline & Loser & 61.6 & 6.78 \\
\hline & Combined & 62.8 & 6.58 \\
\hline & Difference & $\begin{array}{c}2.5^{*} \\
(0.078)^{\#}\end{array}$ & \\
\hline
\end{tabular}

* Significance at the $10 \%$-level

${ }^{\#} t$-test: $p$-value in parentheses, two-sided test

predominant fairness judgment. We find a surprisingly small self-serving bias; i.e., fairness judgments are only weakly role dependent.

Table 2 and Figure 1 show that the average judgment of the fair settlement is strongly skewed away from the equal split toward the proportional split. The average perceived fair share was $62.8 \%$. The fairness judgments do not differ according to gender, age, income, and field of study of the respondents (all $p$-values are at least 0.20). As Figure 1 shows, only a few people thought that the equal split is the fair settlement in the eyes of an arbitrator; almost all people believed that a fair division entitles the winner to considerably more than half of the surplus. The modal judgment is that the fair sharing is a split of the reduced pie in proportion to the claims. A test of proportions confirms that the fraction of people who

Figure 1 Distribution of Fairness Judgments

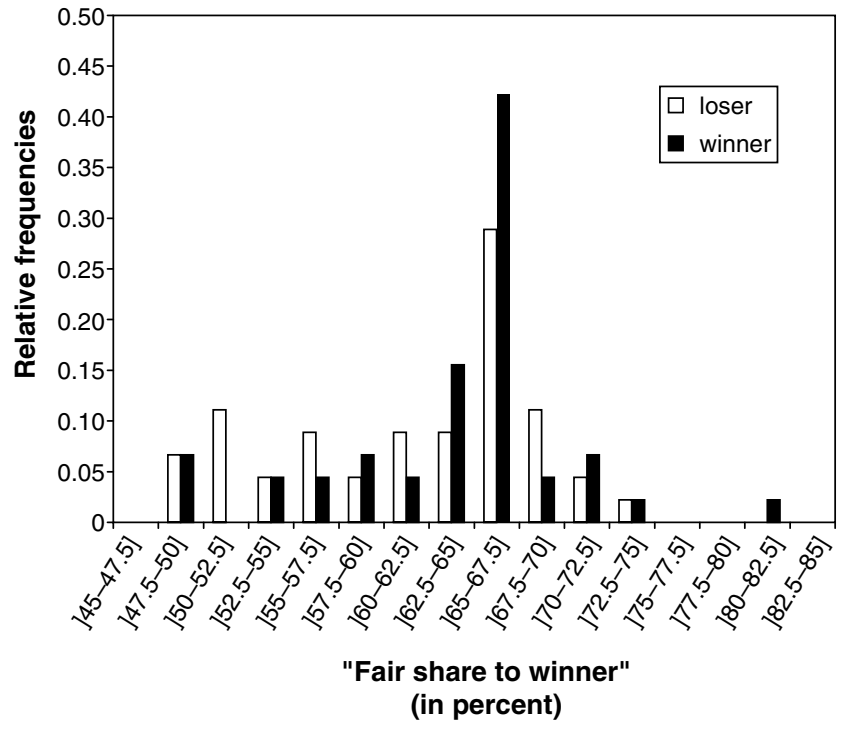


believed that the proportional split is fair is significantly higher than the share of people who considered the equal split as being fair ( $p<0.001$, two-sided). Thus, there can be no doubt that our subjects derived a strong entitlement from the infeasible claims.

Figure 1 and Table 2 also show some differences in fairness judgments between winners and losers. On average, the winners thought that the fair share to the winner according to the arbitrator question is $64.0 \%$, whereas the losers thought that, on average, the fair share is $61.6 \%$. This relatively small difference in fairness judgments is only marginally significant $(p=0.078$, two-sided $t$-test $)$ and suggests a surprisingly weak self-serving bias. The self-serving bias seems to be much smaller than previously observed (e.g., Babcock et al. 1995). It also indicates an important role for losers' obligations, the counterpart of winners' entitlements.

Interestingly, the winner's entitlement is closest to the proportional rule, whereas the loser's entitlement corresponds very closely to the Talmud solution, which grants the loser $39.3 \%$ and the winner $60.7 \%$.

\subsection{The Role of Entitlements in the Bargaining Process}

Although it is remarkable that losers thought they were entitled to less than $40 \%$, one may object that such fairness judgments are vacuous statements. Moreover, the definitions of entitlements and obligations demand that people have a motivational disposition to defend or respect them. Put differently, entitlement effects in bargaining require that we should find a correlation between the fairness judgments and negotiation behavior. However, for at least three reasons, finding such correlations is not straightforward. First, it must be the case that fairness judgments are not only cheap talk, but that negotiators actually feel committed to their entitlements and express this in their bargaining behavior. In other words, the entitlements (as elicited by the fairness judgments) should serve as an anchor (Tversky and Kahneman 1974) for negotiation behavior. Second, negotiators may have to compromise on their entitlements if they want to avoid an impasse, which may weaken a correlation even if people feel committed to their entitlements. Third, bargaining tactics, like toughness or stubbornness, might undermine any entitlement effect.

If fairness judgments matter, we expect that they influence the negotiation process as follows: (i) The opening offers of both winners and losers are positively correlated with their respective fairness judgments, and (ii) the larger the difference in fairness judgments between losers and winners is, the longer it takes to reach an agreement, and the smaller are the concessions made during the bargaining process.
Figure 2 and the statistical analyses reported in Tables $4-6$ in the appendix provide the support for our second result:

Result 2. Fairness judgments are statistically significantly correlated with (i) opening offers, (ii) bargaining duration, and (iii) concession behavior.

We will now discuss the support for results (i) to (iii) in turn.

Opening Offers. Figure 2(a) depicts-separately for losers and winners-the opening share to the winner (defined as the very first offer) of a subject who has made an opening offer as a function of this subject's fairness judgment. As the scatter plot demonstrates and the Spearman rank correlation verifies, there is a highly significantly positive correlation between the fairness judgments of losers and the loser's opening shares to the winner. ${ }^{6}$ While losers exhibit a considerable variation in their fairness judgments and opening offers, the fairness judgments of winners who made an opening offer cluster around the proportional split (leading to an insignificant correlation). Accordingly, winners tend to ask for the proportional split or more.

Figure 2(a) also shows that the opening offers depended on who was making them (the difference in opening offers between losers and winners is highly significant, one-sided Mann-Whitney test; $p<0.01$ ). The observation that fairness judgments have significantly influenced the opening offers allows us to separate the entitlement effect in the opening offers from a strategic offer effect. On average, winners who made an opening offer thought that a winner share of $66.7 \%$ was fair and actually asked for $71.6 \%$; losers who made an opening offer judged a share of $61.1 \%$ as fair and offered only $52.4 \%$. Thus, the strategic offer effect amounts to 4.9 percentage points for winners and to 8.8 percentage points for losers. Both effects are highly significant according to Wilcoxon signedrank tests that compare opening offers and fairness judgments $(p<0.01)$. However, the magnitude of the strategic offer effect is not role dependent $(p=0.132$, one-sided Mann-Whitney test).

Bargaining Duration and Concession Behavior. It is natural to look at bargaining duration as a function of the tension in fairness judgments. Figure 2(b) plots the bargaining duration against the difference in

\footnotetext{
${ }^{6}$ Due to distorting graphical scale effects, Figure 2(a) does not contain the "outlier" $(50,2.4)$. In the calculation of the Spearman rank correlation coefficient reported in the figure, the outlier is included, however. The positive correlation also holds if we remove it: $\rho=0.47 ; p=0.011$. These findings are also corroborated by a Tobit regression analysis, which can be found in Table 4 in the appendix.
} 
Figure 2 Bargaining Behavior Is Influenced by the Fairness Judgments
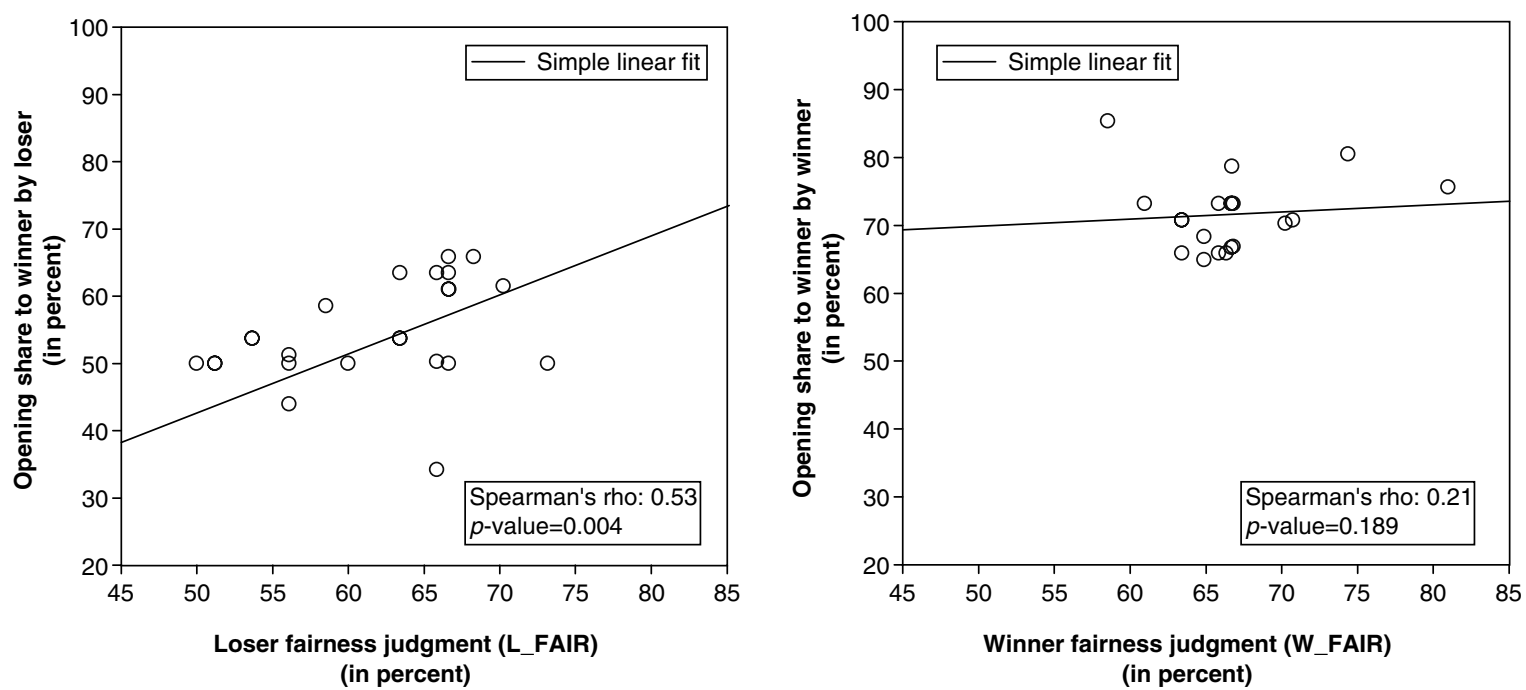

(a) Opening Offers

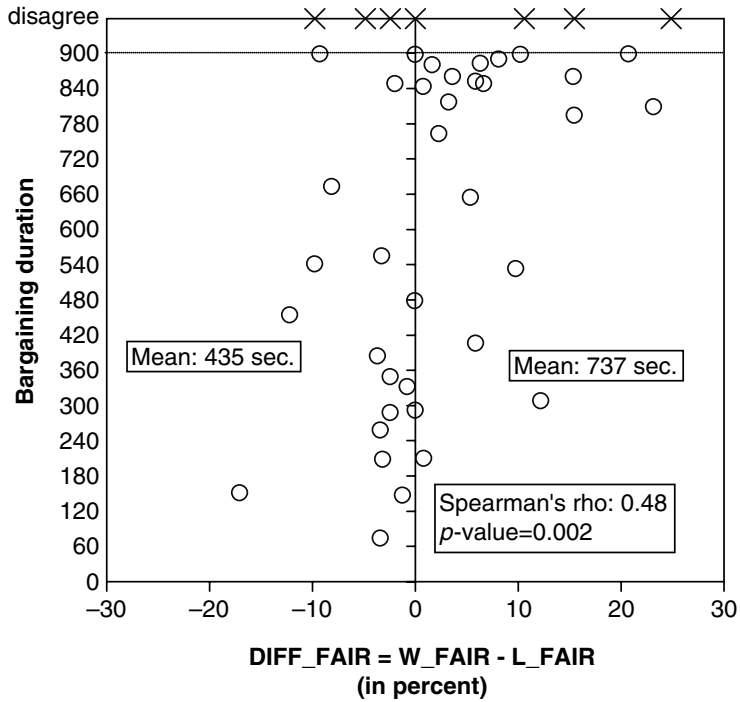

(b) Bargaining Duration

fairness judgments between a winner and a loser (i.e., DIFF_FAIR $=$ W_FAIR - L_FAIR) ${ }^{7}$

The figure nicely shows that there is a significantly positive correlation between the tension in fairness judgments in a bargaining dyad and the bargaining duration (in Figure 2(b) " $x$ " denotes disagreements; they are, however, excluded in the calculation of correlations). We corroborate this observation with several robustness checks in a Tobit regression analysis, which can be found in the appendix.

\footnotetext{
${ }^{7}$ Note that this measure becomes negative if the loser gives more to the winner than the winner gives to herself according to the arbitrator question. We interpret this as observing no tension in the bargaining dyad. Notice further that a positive difference in fairness judgments is equivalent to having inconsistent entitlements (which sum up to more than 100\%) whenever the loser grants the winner at least $50 \%$ of the pie.
}

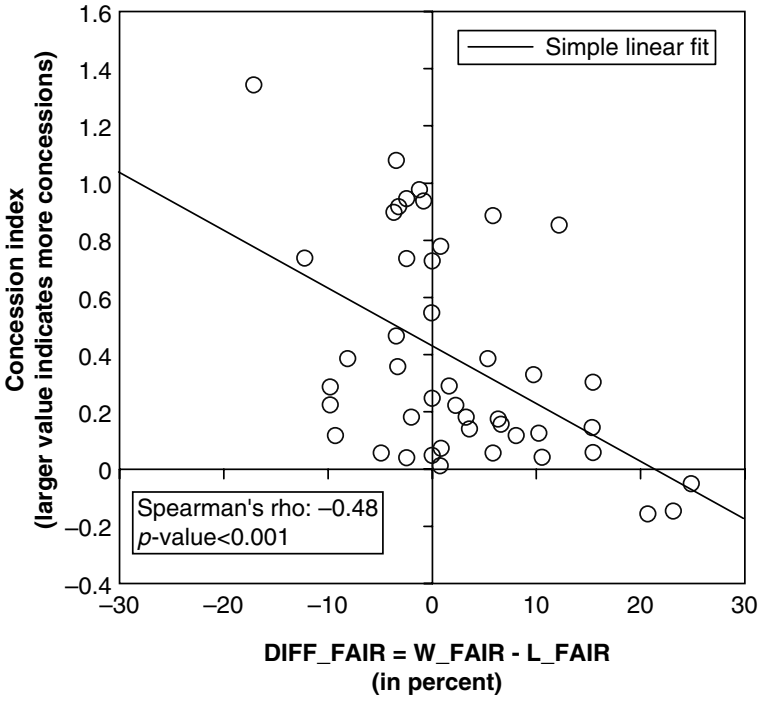

(c) Concession Behavior

On average, it took negotiators 590 seconds to reach an agreement. Bargaining pairs with a negative tension in their fairness judgments reached an agreement in 435 seconds, whereas pairs with inconsistent entitlements (i.e., DIFF_FAIR > 0) needed 737 seconds to strike an agreement. The difference is more than five minutes and is highly significant according to a Mann-Whitney test ( $p<0.002$, one-sided).

Our findings also shed new light on the oftenobserved "deadline effect" in bargaining (Roth et al. 1988). As in many related previous bargaining experiments, most agreements in our experiment were reached in the very last minute; up-to-the-last-minute agreement times are roughly uniformly distributed. Inconsistent fairness judgments were a major determinant of the deadline effect in our experiments. On average, DIFF_FAIR of all pairs who reached an 
agreement in the very last minute was 5.2 percentage points; the average DIFF_FAIR of agreements prior to the last minute was only 0.3 percentage points. This difference is significant according to a Mann-Whitney test ( $p=0.015$, one-sided). Although there may exist strategic reasons to delay the negotiations (e.g., Fershtman and Seidmann 1993), our results show that delay is significantly affected by differences in fairness judgments. Thus, tension in entitlements is an independent cause of delay. This also holds if we control for the difference in opening offers (see the regression model in the appendix).

As we have seen, opening offers of losers and winners are, on average, rather far apart from each other. Thus, concessions are necessary to reach an agreement. To be able to relate concessions to fairness judgments, we need to develop a statistic that captures concession behavior. To our knowledge, no concession indices yet exist that take the peculiarities of concessions in freeform bargaining into account. We therefore developed indices that measure concession behavior.

In general, a concession can be seen as an offer that makes the opponent better off. However, the same absolute concession can be perceived as small when the standing offers are far apart, or generous when the standing offers are close to each other. Furthermore, concession behavior can also be weighted along the time dimension. Someone who is willing to give in early in the negotiation might be seen as more compromising and less tough than someone who concedes the same amount only if an impasse is imminent.

The "magnitude" of a concession depends on the "current bargaining area," which we define as the difference in standing offers of the two negotiators. Because it is in the nature of concessions that they reduce the bargaining area, it is obvious that the same absolute concession can actually be large or small. Therefore, we normalize concessions by the current bargaining area. This gives us the relative concession as one measure of concession behavior. In the following, we will investigate three individual statistics of the concession behavior of a negotiator: (i) the average relative concession; (ii) the average concession time, i.e., the average point in time a negotiator made a concession; and (iii) the average time-weighted relative concession, i.e., a combination of the average relative concession and the average concession time. ${ }^{8}$

We expect that the difference in fairness judgments will influence individual concessions. However, pre-

\footnotetext{
${ }^{8}$ The exact definitions are as follows. A relative concession of a winner is defined as the difference between a winner's standing offer (in winner share) and his new offer (in winner share) divided by the current bargaining area. The current bargaining area is given by the difference between the standing offer of the winner (as winner share) and the standing offer of the loser (as winner share). A relative concession of a loser is defined analogously. For example, if
}

vious research suggests that concession behavior is to some extent reciprocal; i.e., concessions made by one negotiator also depend on concessions made by the opponent (see, e.g., Kuon and Uhlich 1993, and Hennig-Schmidt 1999). Indeed, we find that concessions and concession times are significantly correlated between negotiators. To cope with this problem, we restrict our analysis to pairs of bargainers by taking for each pair the sum of the particular individual concession statistics as the relevant unit of observation.

We conjecture that the larger the difference in fairness judgments, the smaller concessions will be and/or the later they will occur. We expect, therefore, in statistical terms at the pair level that (i) the sum of average relative concessions is negatively correlated with DIFF_FAIR, (ii) the sum of average concession times is positively correlated with DIFF_FAIR, and (iii) the sum of average time-weighted relative concessions is negatively correlated with DIFF_FAIR.

The Spearman rank-order correlations (one-sided tests) support these hypotheses: They are (i) -0.28 $(p<0.05)$, (ii) $0.49(p<0.001)$, and (iii) $-0.48(p<$ 0.001 ), respectively. Figure 2(c) illustrates the connection between DIFF_FAIR and concession behavior for our most encompassing concession statistics, the sum of average time-weighted relative concessions, which for brevity we call "concession index" in the figure. According to this measure, a given relative concession is weighted less the later the concession is made. Thus, a larger value of this concession index corresponds to a higher willingness to concede. The figure nicely shows that pairs with a low concession index also strongly disagree on what a fair division of the surplus is (lower-right part of the figure). Conversely, pairs who do not differ in their fairness judgments are

the standing offers of a winner and a loser are 0.7 and 0.5 , respectively (i.e., the current bargaining area is 0.2 ), and the winner now demands only 0.6 for himself, then the absolute concession is 0.1 and the relative concession is $0.5(=0.1 / 0.2)$. The magnitude of 0.5 can be interpreted as going halfway toward an agreement. The initial bargaining area is assumed to be the difference in claims (i.e., $(1660-830) / 2050 \approx 0.4)$. A concession leading to a new offer that precisely matches the opponent's standing offer gives a relative concession of 1 . Therefore, an acceptance is calculated as a relative concession of 1 . The summary statistics average relative concession of a bargainer is just the average of all of his relative concessions made during the bargaining process.

The average concession time of a bargainer is defined as the sum of concession times divided by the number of concessions.

A time-weighted relative concession is a relative concession (as defined above) multiplied by ( $901-$ time of concession) if the concession is positive and multiplied by time of concession if the concession is negative, respectively. This measure has the property that a given positive (negative) relative concession gets the less (more) weight the later the concession is made. The statistic we use is the average of all time-weighted relative concessions of a negotiator. 
those that also make relatively large and early concessions (upper-left part). ${ }^{9}$ All of our results are corroborated by regression analyses (see the appendix).

Thus, the greater the tension with respect to fairness judgments in a bargaining pair, the later concessions are made and the smaller the concessions are. These findings also provide an explanation for why we observe a significant relationship between fairness judgments and bargaining duration.

\subsection{Entitlements and Agreements}

The ultimate interest in a negotiation is to reach an agreement. In previous symmetric free-form bargaining experiments with zero conflict payoffs, an exact equal split of the surplus has been observed almost unanimously (see, e.g., Nydegger and Owen 1975). If the infeasible claims influence the entitlements and thereby the terms of agreement, then the distribution of agreements should be skewed away from the equal split.

In this case, there should also be a correlation of reached agreements with the fairness judgments. We expect that, in a pair, the agreed share to the winner is positively correlated with the fairness judgment of a winner and the fairness judgment of a loser. The rationale for this hypothesis is that the more any of the bargainers in a pair would give to the winner according to the arbitrator question, the "easier" it should be to agree on a higher winner share.

Our third result establishes the influence of the fairness judgments in shaping the agreements.

Result 3. (i) We find a strong entitlement effect in the agreements: On average, the agreed share to the winner is $60.5 \%$. (ii) The fairness judgments of winners and losers are highly significantly positively correlated with the agreements. (iii) Our results suggest that disagreements are indirectly related to the fairness judgments.

Figure 3 provides graphical support for our results 3(i) and 3(ii). Figure 3(a) shows the distribution of agreements in the experiment. It provides strong evidence for an entitlement effect in the reached agreements. The distribution of agreements is highly significantly skewed away from the equal split $(p<$ $0.0001, t$-test, one-sided). Only $11 \%$ of the agreements implemented the equal split. The most common agreements occurred at $67 \%$, i.e., the proportional split according to the claims. ${ }^{10}$ We even observe agreements above the proportional split. The mean

\footnotetext{
${ }^{9}$ The correlation result is robust with respect to the "outlier" in the upper-left part of the figure. Without this data point, Spearman's rho becomes -0.44 with a one-sided $p$-value of 0.0015 .

${ }^{10}$ The reader might ask how robust this result is to different claims. For the sake of not overburdening the analysis of entitlements in bargaining, we have in this paper refrained from manipulating claims levels. However, in Gächter and Riedl (2004) we investigate
}

agreed share to the winner was $60.5 \%$, which comes very close to the Talmud solution that grants the winner $60.7 \%$. In our view, this provides strong evidence for an entitlement effect in the agreements.

Figure 3(b) depicts the correlation of reached agreements and the fairness judgments. The results are consistent with all of our previous observations. We find a strongly positive correlation between fairness judgments of winners and losers and the agreed share to the winner. The Spearman rank correlation between the fairness judgment of a winner and the reached agreement is positive and highly significant ( $\rho=0.55$, $p<0.001$, one-sided test); for the loser, it is as well significantly positive $(\rho=0.31, p=0.033$, one-sided test). The robust Tobit estimates that are reported in Table 7 of the appendix strengthen these findings. Thus, fairness judgments not only significantly shape the bargaining process, but agreements as well.

Additional evidence for the importance of entitlements comes from the messages that could be sent along with proposals. From the total of 406 proposals, 287 were accompanied by some message. Most of them contained text like "I want more" or "Your offer was too small." However, 70 messages contained text with arguments explicitly referring to fairness considerations and/or entitlements and obligations. Fortytwo of these messages were sent by winners and 28 by losers. In 33 cases, winners argued for unequal divisions near the proportional split because of better performance and performance-based fairness considerations. Interestingly, in almost $50 \%$ of the cases, losers also argued along these lines (although their proposed winner share was mostly smaller than the winner share demanded by the winner). The other half of the classified loser messages contained arguments in favor of the equal split. In contrast, only 4 of the 33 messages of winners contained such arguments. In our view, this supports the conclusion that winners' bargaining behavior was strongly influenced by entitlements derived from the infeasible claims. Furthermore, it seems that a nonnegligible part of losers actually felt obliged to concede the winners significantly more than half of the pie.

An important issue in the study of negotiations is the explanation of disagreements. In our experiment we observed a total of seven disagreements $(16 \%$ of all bargaining encounters). Although the percentage of disagreements is completely in line with previous findings (see Roth et al. 1988), in absolute terms there are still just a few cases in number. We can therefore sketch only possible determinants of disagreements.

the impact of different claims levels on normative judgments and actual negotiations in a slightly different context. We find that, by and large, the proportional rule explains the data well. 


\section{Figure 3 Agreements}

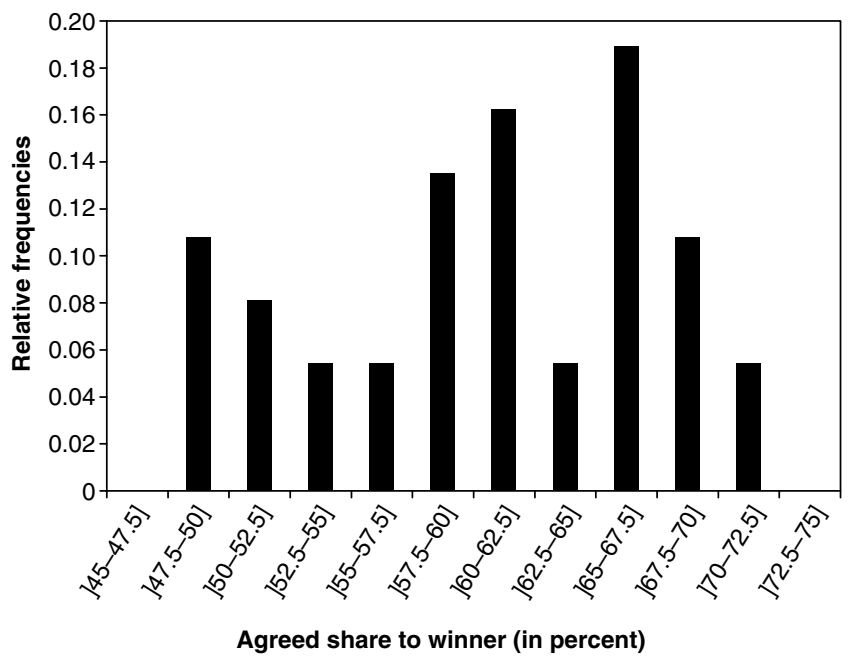

(a) Distribution of Agreements
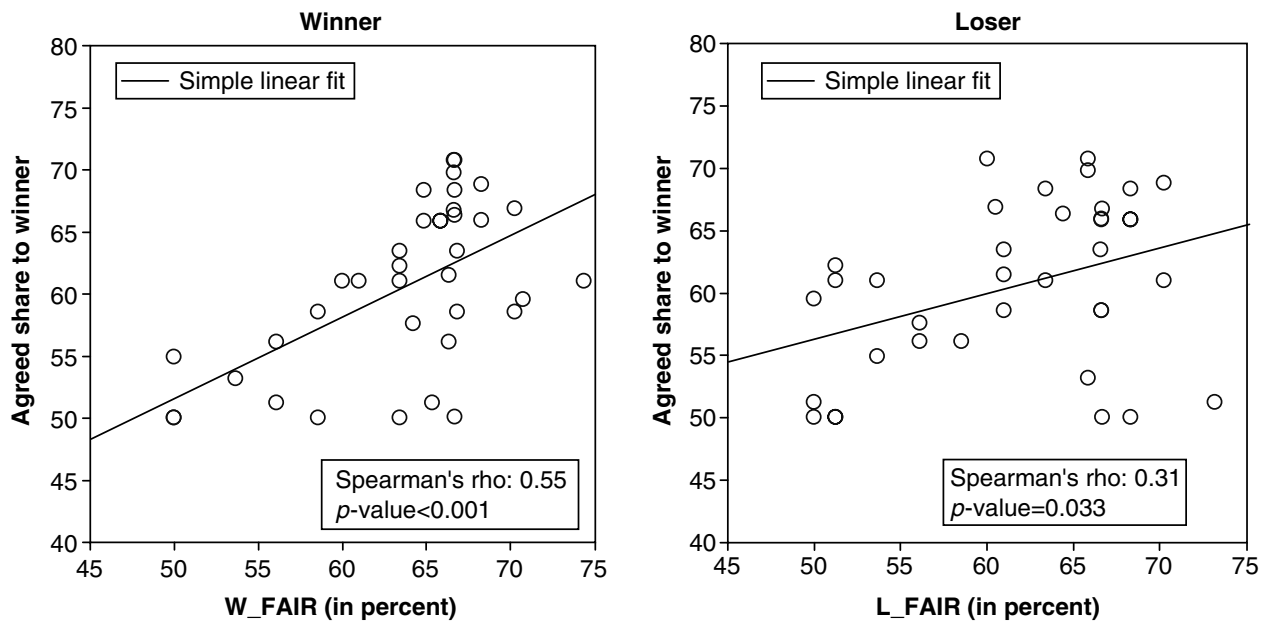

(b) Agreements Are Influenced by the Fairness Judgments

In accord with our previous analyses, we expect that bargaining pairs that disagreed are characterized by larger differences in fairness judgments than the pairs that reached an agreement. Indeed, the difference in fairness judgments is lower for pairs that found a settlement than for those that did not ( 2 and 4.8 percentage points, respectively). However, because this difference is statistically not significant $(p=0.380$, one-sided Mann-Whitney test), we cannot claim to detect a direct influence of the differences in fairness judgments on the disagreements (see also Figure 2(b)).

A further analysis, however, shows that the difference in first offers is significantly lower for agreements than for disagreements. The difference in first offers of winner shares of pairs who reached an agreement is 13.7 percentage points, whereas for pairs that did not reach an agreement it is 27.6 percentage points. This difference is highly significant according to a MannWhitney test ( $p=0.003$, one-sided). Furthermore, the average concession time is significantly lower for agreements than for disagreements. The average relative concession and the average time-weighted relative concession are significantly larger for agreements than for disagreements (all $p$-values $<0.001$, one-sided Mann-Whitney test). Together with our previous findings that both opening offers and concession behavior are significantly influenced by the fairness judgments, this establishes an indirect relation of the fairness judgments with the settlement rates.

Another interesting question is whether the entitlements actually paid off, given that they might have led to bargaining impasse and zero payoffs. A calculation of Spearman rank-order correlations between final payoffs (including the zero disagreement payoffs) and the fairness judgments reveals a significantly positive correlation of the winners' final payoff with their fairness judgments $(\rho=0.33 ; p=0.014$, one-sided). For losers, the correlation between the 
final payoff and fairness judgments (in "winner share") is weakly significantly negative ( $\rho=-0.204$; $p=0.092$, one-sided). Thus, in our experiment entitlements did pay off-at least for winners.

\section{The Role of the Self-Serving Bias in the Entitlements}

Entitlements and obligations by negotiators are grounded in what they perceive as being a "fair" agreement. In our experiment, the fairness judgments of losers were lower than those of the winners, which suggests the existence of a self-serving bias among our bargainers (see Table 2). However, the difference is surprisingly small in magnitude and only weakly significant. We find this to be a surprising result, given (i) the findings of previous research, and (ii) the existence of possible multiple focal points of our bargaining problem (see also Camerer and Loewenstein 1993, Babcock and Loewenstein 1997). It seems that the perceived entitlements and obligations in our bargaining-with-claims experiment were strong enough to weaken any self-serving bias considerably. This holds especially for the losers who largely did not think that the equal split is fair. A speculative explanation for this might be that we provided the subjects with an explicit statement of the relevant precedent, i.e., the historical claims. Because self-servingly biased fairness considerations increase the likelihood of bargaining impasse (Babcock et al. 1995), precedents that presumably reinforce a common understanding of entitlements might be a means to reduce disagreements in negotiations.

The knowledge of one's role when making the fairness judgment may nevertheless have influenced judgments, and hence, negotiation behavior. This raises the question of to what extent the timing of our "arbitrator question" affects stated fairness judgments and bargaining behavior. To test that, we ran a control experiment-with another 44 subjects (22 pairs)where fairness judgments were made behind the "veil of ignorance." This experiment was an exact copy of the experiment of our main condition, with one important exception. In the control experiment subjects had to answer the arbitrator question before they knew whether they would be the winner or the loser of the performance quiz. Actually, the arbitrator question was asked right after reading the instructions and before performing the knowledge quiz (this procedure is adapted from Babcock et al. 1995). Note that in this setting, fairness judgments, by definition, cannot be self-servingly biased.

We summarize the findings of this control experiment in the following result.

Result 4. If subjects assess fairness before they know their role in the negotiations, the fairness judgments of ex post winners and losers do not differ.
Furthermore, in stark contrast to our main condition, the fairness judgments made behind the "veil of ignorance" cannot explain the variation in bargaining behavior in any phase of the negotiations. The average bargaining behavior is similar to that in our main condition.

Table 3 provides the support for the results of the control condition. It documents the Spearman rankorder correlations for each of our bargaining statistics with the relevant fairness judgment measures (see also the note at the bottom of the table). For the sake of comparisons, this table also summarizes the means (and standard deviations) of the main condition, as well as the control condition. In the last column we report the $p$-values of statistical comparisons of the main condition with the control condition.

The most important findings are as follows. First, fairness judgments are very similarly distributed in the control experiment as they are in the main experiment (Kolmogorov-Smirnov test, $p=0.728$ ). Second, as expected, fairness judgments of ex post winners and losers are virtually the same $(p=0.804$, twosided Mann-Whitney test) and lie between the fairness judgments of winners and losers in our main condition. Third, in stark contrast to our main condition, fairness judgments made behind the "veil of ignorance" do not explain the variation in bargaining behavior (see column "Correlation" in Table 3). Not a single correlation of a particular bargaining statistic with the respective fairness judgment is significant at the conventional levels. Because fairness judgments are identically distributed in our control experiment and in our main experiment, this lack of correlation is unlikely to be due to a lack of variation of fairness judgments. Fourth, there are no treatment differences between the levels of our variables of bargaining behavior in our main condition and the control condition. The only possible exception is bargaining duration, which was weakly significantly longer in the control condition than in the main condition.

The agreements are of particular interest. As in our main condition, we also find a strong entitlement effect in our control condition. The mean agreed share to the winner is $62.3 \%$ and not significantly different from the $60.5 \%$ observed in our main condition ( $p=0.495$, two-sided Mann-Whitney test). Although there is no correlation between the variation in fairness judgments and the variance of the reached agreements, notice that the levels of agreement and fairness judgments correspond closely.

The observations summarized in Results 2 to 4 that: (i) with role knowledge, fairness judgments and negotiation behavior are highly significantly correlated; (ii) without role knowledge, the fairness judgments cannot explain the variation in bargaining behavior; 
Table 3 Summary Statistics and Correlations with Fairness Judgment (Main Condition and Control Condition)

\begin{tabular}{|c|c|c|c|c|c|c|}
\hline & \multicolumn{2}{|c|}{ Main condition } & \multicolumn{3}{|c|}{ Control condition } & \multirow{2}{*}{$\begin{array}{l}\text { Comparison of } \\
\text { main and control } \\
\text { condition } p \text {-values }\end{array}$} \\
\hline & $\begin{array}{c}\text { Mean } \\
\text { (Std. dev.) }\end{array}$ & $N$ & $\begin{array}{c}\text { Mean } \\
\text { (Std. dev.) }\end{array}$ & $N$ & Correlation & \\
\hline \multicolumn{7}{|l|}{ Fairness judgments (in percent) } \\
\hline Winner & $\begin{array}{l}64.0 \\
(6.2)\end{array}$ & 45 & $\begin{array}{l}61.8 \\
(7.1)\end{array}$ & 22 & & $0.287^{d}$ \\
\hline Loser & $\begin{array}{l}61.6 \\
(6.8)\end{array}$ & 45 & $\begin{array}{l}62.3 \\
(6.6)\end{array}$ & 22 & & $0.634^{d}$ \\
\hline \multicolumn{7}{|l|}{ Opening offers (in percent) } \\
\hline Winner & $\begin{array}{l}71.6 \\
(5.4)\end{array}$ & 20 & $\begin{array}{c}70.8 \\
(10.5)\end{array}$ & 12 & $-0.21^{\mathrm{a}}$ & $0.327^{d}$ \\
\hline Loser & $\begin{array}{c}52.4 \\
(12.8)\end{array}$ & 25 & $\begin{array}{l}54.3 \\
(4.4)\end{array}$ & 10 & $0.00^{\mathrm{b}}$ & $0.970^{d}$ \\
\hline Bargaining duration (in seconds) & $\begin{array}{c}590 \\
(278)\end{array}$ & 37 & $\begin{array}{c}718 \\
(228)\end{array}$ & 17 & $0.30^{c}$ & $0.061^{d}$ \\
\hline \multicolumn{7}{|l|}{ Sum of average } \\
\hline Relative concessions & $\begin{array}{c}0.614 \\
(0.452)\end{array}$ & 44 & $\begin{array}{c}0.537 \\
(0.388)\end{array}$ & 22 & $-0.14^{c}$ & $0.496^{d}$ \\
\hline Concession times & $\begin{array}{l}767 \\
(336)\end{array}$ & 44 & $\begin{array}{c}872 \\
(251)\end{array}$ & 22 & $0.07^{c}$ & $0.237^{d}$ \\
\hline $\begin{array}{l}\text { Time-weighted relative } \\
\text { concessions }\end{array}$ & $\begin{array}{c}0.389 \\
(0.377)\end{array}$ & 44 & $\begin{array}{c}0.286 \\
(0.336)\end{array}$ & 22 & $-0.10^{c}$ & $0.334^{d}$ \\
\hline Agreements (in percent) & $\begin{array}{l}60.5 \\
(6.7)\end{array}$ & 37 & $\begin{array}{l}62.3 \\
(4.2)\end{array}$ & $\begin{array}{l}17 \\
17\end{array}$ & $\begin{array}{r}-0.29^{\mathrm{a}} \\
0.32^{\mathrm{b}}\end{array}$ & $0.495^{d}$ \\
\hline Disagreement rate (in percent) & 15.9 & 44 & 22.7 & 22 & & $0.515^{\mathrm{e}}$ \\
\hline \multicolumn{7}{|l|}{ Final payoffs (in percent) } \\
\hline Winner & $\begin{array}{c}50.9 \\
(23.2)\end{array}$ & 44 & $\begin{array}{c}48.1 \\
(27.0)\end{array}$ & 22 & $-0.00^{\mathrm{a}}$ & $0.962^{d}$ \\
\hline Loser & $\begin{array}{c}33.2 \\
(15.8)\end{array}$ & 44 & $\begin{array}{c}29.1 \\
(16.6)\end{array}$ & 22 & $0.05^{b}$ & $0.342^{d}$ \\
\hline
\end{tabular}

Notes. Correlation statistics are Spearman's rho. ${ }^{a}$ Correlation with winner fairness judgment (W_FAIR). ${ }^{b}$ Correlation with loser fairness judgment (L_FAIR). ${ }^{\circ}$ Correlation with difference in fairness judgments. (DIFF_FAIR $=$ W_FAIR $-L_{-} F A I R$ ). All correlations are insignificant; one-sided tests. ${ }^{d}$ Two-sided Mann-Whitney tests. ${ }^{e}$ Two-sided Fisher's exact test.

and (iii) the average negotiation behavior in our control experiment is not statistically significantly different from the main experiment, seem to be puzzling at first sight. However, research on the "hot-cold empathy gap," which is a pervasive phenomenon in decision making (see, e.g., Loewenstein 2000) suggests an explanation. Being in the "hot state" of knowing one's economic position when making a fairness judgment may lead to a (subconscious) commitment to the stated fairness assessments, which may be reinforced by a self-serving bias. These feelings of commitment to (biased) fairness judgments are likely to shape behavior. This explains why bargaining behavior is strongly correlated with stated fairness judgments in our main condition (Results 2 and 3). In our control condition, negotiators made their fairness judgments in the "cold state" of not yet knowing their role. The "cold" fairness judgments may have led to an insufficiently strong commitment to influence bargaining behavior. Once bargainers learned their claims and moved into the "hot state" of knowing their economic position, they may have reassessed their fairness judgments and gotten anchored on them in a way similar to that of the subjects of our main condition.

\section{Concluding Remarks}

There can be no doubt that subjects in our experiments derived a "moral property right" from the claims they have earned. ${ }^{11}$ By letting subjects negotiate in a situation where they were confronted with infeasible claims, we created a testbed for studying entitlements and obligations, which are not abstract legal rights or liabilities. The claims were economically irrelevant, and yet they instilled in our subjects

\footnotetext{
${ }^{11}$ In this sense, our study extends earlier research on entitlements. For instance, Güth and Tietz (1985), Hoffman and Spitzer (1985), and Hoffman et al. (1994) investigated how role assignment (earned or randomly assigned) influenced allocation decisions in ultimatum and dictator games. Babcock et al. (1995) examined the role of self-servingly biased entitlements in bargaining. For a discussion of experiments on entitlements, see Camerer (2003). None of these studies investigated entitlements derived from infeasible claims.
} 
a subjectively perceived right or obligation. This is reflected in the fairness judgments. Moreover, as the negotiation behavior shows, subjects with the high claim were willing to defend their moral property rights, and subjects with the low claim largely felt obliged to accept them. Our results indicate that the entitlements expressed by negotiators are not only used for strategic purposes, but bear a close relationship to what negotiators believe and actually do. Fairness is not just a smoke screen to advance self-interest.

Our findings suggest an interesting relation between "legal" and "moral" property rights. Legal property rights are crucial for the usual Coasean reasons. ${ }^{12}$ Because the legal property rights were the same for the bargaining partners, our results show that entitlements constitute a moral property right that also exists irrespective of the legal rights. Thus, in negotiations, bargainers will also put their moral property rights on the bargaining table, and this will strongly influence the bargaining process and outcome.

\section{Acknowledgments}

This paper is part of the EU-TMR research network ENDEAR (FMRX-CT98-0238) and the research project on "Strategic Bargaining and Coalition Formation" financed by the Oesterreichische Nationalbank (project number: 6933). The authors thank an anonymous associate editor and two referees of this journal for their valuable comments, which helped to improve the manuscript. They are very indebted to Franz Brandel, who wrote the experimental software. Caroline Eckhart, Monika Egelwolf, Helmut Elsinger, Markus Knell, Armin Schwienbacher, and Jana Vyrastekova provided excellent research assistance. The authors especially thank Jonas Agell, Wulf Albers, Marc Bettzüge, Iris Bohnet, Gary Bornstein, Colin Camerer, Rachel Croson, Martin Dufwenberg, Catherine Eckel, Armin Falk, Ernst Fehr, Lorenz Götte, Heike Hennig-Schmidt, Guillermina Jasso, James Konow, Michael Kosfeld, Barbara Krug, Axel Ockenfels, Roald Ramer, Elke Renner, Tom Rietz, Bettina Rockenbach, Bradley Ruffle, Randolph Sloof, JeanRobert Tyran, Bodo Vogt, Nick Vriend, and participants of conferences and seminars in Amsterdam, Bari, Barcelona, Bielefeld, Erfurt, Lake Tahoe, Mannheim, New Orleans, Stockholm, and Zurich for their helpful comments.

\section{Appendix}

Here we provide robustness tests with the help of robust Tobit regressions for our results presented in $\$ \S 3.2$ to 3.3 . We proceed in the same sequence as in the main text by first reporting the results concerning the bargaining process, i.e., opening offers, bargaining duration and concessions, followed by the results concerning the agreements. The regression results confirm the results stated in the main text.

${ }^{12}$ For experimental evidence on this, see, e.g., Harrison and McKee (1985), Hoffman and Spitzer (1985), Croson and Johnston (2000).
Table 4 Explaining the Opening Offers (Robust Tobit Estimates)

\begin{tabular}{|c|c|c|c|c|}
\hline \multirow[b]{3}{*}{$\begin{array}{l}\text { Independent } \\
\text { variables }\end{array}$} & \multicolumn{4}{|c|}{ Dependent variable: Opening share to winner } \\
\hline & \multicolumn{2}{|c|}{ Loser\& } & \multicolumn{2}{|c|}{ Winner } \\
\hline & $\begin{array}{l}\text { Coefficient } \\
\text { (Std. err.) }\end{array}$ & $z$-value & $\begin{array}{l}\text { Coefficient } \\
\text { (Std. err.) }\end{array}$ & $z$-value \\
\hline Constant & $\begin{array}{l}0.286^{* * *} \\
(0.105)\end{array}$ & 2.72 & $\begin{array}{l}0.648^{* * *} \\
(0.230)\end{array}$ & 2.82 \\
\hline L_FAIR & $\begin{array}{l}0.420^{* *} \\
(0.187)\end{array}$ & 2.25 & & \\
\hline W_FAIR & & & $\begin{array}{c}0.102 \\
(0.337)\end{array}$ & 0.30 \\
\hline Log- $L$ & & & & \\
\hline Wald $\chi^{2}$ & & & & \\
\hline$N$ & & & & \\
\hline
\end{tabular}

Notes. Robust standard errors in parentheses. ${ }^{* * *}$ Significance at the $1 \%$ level. ${ }^{* *}$ At the $5 \%$ level. ${ }^{*}$ At the $10 \%$ level; one-sided tests. ${ }^{\ddagger}$ Significance at the $5 \%$ level; two-sided tests. ${ }^{\&}$ The outlier $(0.5,0.024)$ has been removed.

Opening Offers. The results reported in Table 4 confirm those provided in the main text (see Result 2(i)). ${ }^{13}$ Like the Spearman rank-order correlations, the regression results show that the opening offers made by losers are highly correlated with their fairness judgments. For winners, the variation in fairness judgments cannot explain the variation in opening offers. Note, however, that the constant is, with 0.648 , close to the proportional split and almost the same as the average fairness judgments made by winners. This is a consequence of the fact that the winners' fairness judgments show relatively little variation and are clustered around the proportional split.

Bargaining Duration. The result of Regression Model 1 in Table 5 resembles the Spearman rank-order statistics in the main text. The regression outcome confirms that a higher difference (i.e., tension) in fairness judgments between the winner and the loser in a bargaining pair significantly increases the time till an agreement is reached $(p<0.01$, one-sided). Model 2 shows that this result is robust when taking the difference in first offers (i.e., the difference in the opening offer and the first counteroffer) into account. Both the difference in first offers and the difference in fairness judgments significantly increase the bargaining duration $(p<0.01$ in both cases, one-sided tests). In Model 3, we investigate how the fairness judgment of the loser and the winner separately influence bargaining duration (again accounting for the difference in first offers). The hypotheses are that the more the loser would give to the winner according to the arbitrator question, the faster an agreement is reached. The more the winner would give to the winner according to the arbitrator question, the longer it will take to reach an agreement. As the results for Model 3 show, both hypotheses are confirmed $(p=0.10$ and $p<0.01$ for L_FAIR and W_FAIR, respectively). Interestingly, the fairness judgment of the winner has a much stronger impact on bargaining duration than that of the loser.

${ }^{13}$ In the table, L_FAIR represents the losers' fairness judgment and W_FAIR the winners' fairness judgment (both in winner shares). 
Explaining Bargaining Duration (Robust Tobit Estimates)

\begin{tabular}{|c|c|c|c|c|c|c|}
\hline \multirow[b]{3}{*}{$\begin{array}{l}\text { Independent } \\
\text { variables }\end{array}$} & \multicolumn{6}{|c|}{ Dependent variable: Agreement time } \\
\hline & \multicolumn{2}{|c|}{ Model 1} & \multicolumn{2}{|c|}{ Model 2} & \multicolumn{2}{|c|}{ Model 3} \\
\hline & $\begin{array}{l}\text { Coefficient } \\
\text { (Std.err.) }\end{array}$ & $z$-value & $\begin{array}{c}\text { Coefficient } \\
\text { (Std.err.) }\end{array}$ & $z$-value & $\begin{array}{l}\text { Coefficient } \\
\text { (Std.err.) }\end{array}$ & $z$-value \\
\hline Constant & $\begin{array}{l}559.9^{* * *} \\
(43.3)\end{array}$ & 12.93 & $\begin{array}{l}436.8^{* * * *} \\
(51.8)\end{array}$ & 8.43 & $\begin{array}{c}-282.3 \\
(381.0)\end{array}$ & -0.74 \\
\hline DIFF_FAIR & $\begin{array}{c}1,486.9^{* * *} \\
(373.8)\end{array}$ & 3.98 & $\begin{array}{c}1,228.3^{* * *} \\
(326.1)\end{array}$ & 3.77 & & \\
\hline L_FAIR & & & & & $\begin{array}{r}-743.2^{*} \\
(451.9)\end{array}$ & -1.65 \\
\hline W_FAIR & & & & & $\begin{array}{c}1,869.9^{* * *} \\
(429.4)\end{array}$ & 4.36 \\
\hline DIFF_FIRST & & & $\begin{array}{l}935.3^{* * *} \\
(284.0)\end{array}$ & 3.29 & $\begin{array}{c}1,024.1^{* * *} \\
(225.4)\end{array}$ & 4.54 \\
\hline Log- $L$ & & & & & & \\
\hline Wald $\chi^{2}$ & & & & & & \\
\hline$N$ & & & & & & \\
\hline
\end{tabular}

Notes. Robust standard errors in parentheses. ${ }^{* * *}$ Significance at the $1 \%$ level. ** At the $5 \%$ level. ${ }^{*}$ At the $10 \%$ level; one-sided tests. ${ }^{\circ}$ Significance at the $1 \%$ level; two-sided tests.

Table 6 Explaining Concessions (Robust Tobit Estimates)

\begin{tabular}{|c|c|c|c|c|c|c|c|c|}
\hline \multirow[b]{4}{*}{$\begin{array}{l}\text { Independent } \\
\text { variables }\end{array}$} & \multicolumn{8}{|c|}{ Dependent variables } \\
\hline & \multirow{2}{*}{\multicolumn{2}{|c|}{$\begin{array}{c}\text { Sum of average } \\
\text { relative concessions } \\
\text { Model } 1\end{array}$}} & \multicolumn{4}{|c|}{ Sum of average concession times } & \multirow{2}{*}{\multicolumn{2}{|c|}{$\begin{array}{c}\text { Sum of average } \\
\text { time-weighted } \\
\text { relative concessions } \\
\text { Model } 3\end{array}$}} \\
\hline & & & \multicolumn{2}{|c|}{ Model 2a } & \multicolumn{2}{|c|}{ Model 2b } & & \\
\hline & $\begin{array}{c}\text { Coefficient } \\
\text { (Std.err.) }\end{array}$ & $z$-value & $\begin{array}{l}\text { Coefficient } \\
\text { (Std.err.) }\end{array}$ & $z$-value & $\begin{array}{l}\text { Coefficient } \\
\text { (Std.err.) }\end{array}$ & $z$-value & $\begin{array}{l}\text { Coefficient } \\
\text { (Std.err.) }\end{array}$ & $z$-value \\
\hline Constant & $\begin{array}{l}0.656^{* * *} \\
(0.071)\end{array}$ & 9.22 & $\begin{array}{l}722.9^{* * *} \\
(46.6)\end{array}$ & 15.53 & $\begin{array}{l}561.8^{* * *} \\
(59.4)\end{array}$ & 9.46 & $\begin{array}{l}0.440^{* * *} \\
(0.056)\end{array}$ & 7.87 \\
\hline DIFF_FAIR & $\begin{array}{c}-1.677^{* * *} \\
(0.656)\end{array}$ & -2.56 & $\begin{array}{c}1,779.5^{* * *} \\
(406.5)\end{array}$ & 4.38 & $\begin{array}{c}1,580.7^{* * *} \\
(339.1)\end{array}$ & 4.66 & $\begin{array}{c}-2.034^{* * *} \\
(0.506)\end{array}$ & -4.02 \\
\hline DIFF_FIRST & & & & & $\begin{array}{c}1,042.1^{* * *} \\
(243.7)\end{array}$ & 4.28 & & \\
\hline $\log -L$ & & & & & & & -1 & \\
\hline Wald $\chi^{2}$ & & & & & & & 16 & \\
\hline$N$ & & & & & & & & \\
\hline
\end{tabular}

Notes. For the exact definition of the dependent variables, see Footnote 8 . Robust standard errors in parentheses. ${ }^{* * *}$ Significance at the $1 \%$ level. ${ }^{* *}$ At the $5 \%$ level. ${ }^{*}$ At the $10 \%$ level; one-sided tests. ${ }^{\ddagger}$ Significance at the $1 \%$ level, ${ }^{\dagger}$ at the $5 \%$ level; two-sided tests.

Concession Behavior. Table 6 corroborates the findings reported in the main text. For all our concession statisticssum of average relative concessions (Model 1), sum of average concession times (Models 2(a) and 2(b)), and sum of average time-weighted relative concessions (Model 3)-the difference in fairness judgments (DIFF_FAIR) in a dyad has the "right" sign and is highly significant $(p<0.01$ in all cases, onesided tests). Hence, our regression results confirm that the higher the tension in a bargaining pair, the smaller concessions are and the later concessions are made. In principle, it is possible that concession behavior is also influenced by the first offers. The greater the difference is, the more concessions have to be made and/or the larger the concessions have to be to reach an agreement. Our definition of relative concessions accounts for that (see Footnote 8). However, it may be the case that the timing of concessions is influenced by the first offers. Therefore, in Model 2(b) we control for the difference in first offers. The result shows that (i) the difference in fairness judgments stays highly significant and (ii) that the difference in first offers indeed has a significant (positive) impact on the concession time $(p<0.01$ in both cases, one-sided tests).

Agreements. In the main text, we found with the help of Spearman rank-order statistics that the fairness judgments of losers and winners are significantly positively correlated with the agreement (in winner share) reached in a bargaining pair. The regression results shown in Table 7 corroborate this finding. The fairness judgment of losers as well as the fairness judgment of winners exhibit a highly significantly positive coefficient $(p<0.01$ for both variables, one-sided tests). 
Table 7 Explaining Agreements (Robust Tobit Estimates)

\begin{tabular}{|c|c|c|}
\hline \multirow[b]{2}{*}{$\begin{array}{l}\text { Independent } \\
\text { variables }\end{array}$} & \multicolumn{2}{|c|}{$\begin{array}{l}\text { Dependent variable: } \\
\text { Agreed winner share }\end{array}$} \\
\hline & $\begin{array}{l}\text { Coefficient } \\
\text { (Std. err.) }\end{array}$ & $z$-value \\
\hline Constant & $\begin{array}{l}0.022 \\
(0.084)\end{array}$ & 0.26 \\
\hline L_FAIR & $\begin{array}{l}0.309^{* * *} \\
(0.130)\end{array}$ & 2.38 \\
\hline W_FAIR & $\begin{array}{l}0.618^{* * *} \\
(0.121)\end{array}$ & 5.10 \\
\hline $\begin{array}{l}\text { Log-L } \\
\text { Wald } \chi^{2} \\
N\end{array}$ & \multicolumn{2}{|c|}{$\begin{array}{c}59.0 \\
50.62^{\ddagger} \\
37\end{array}$} \\
\hline
\end{tabular}

Notes. Robust standard errors in parentheses. ${ }^{* * *}$ Significance at the $1 \%$ level, one-sided tests. ${ }^{\ddagger}$ Significance at the $1 \%$ level; two-sided tests.

\section{References}

Aumann, Robert J., Michael Maschler. 1985. Game theoretic analysis of a bankruptcy problem from the Talmud. J. Econom. Theory 36 195-213.

Babcock, Linda, George Loewenstein. 1997. Explaining bargaining impasse: The role of self-serving biases. J. Econom. Perspect. 11(1) 109-126.

Babcock, Linda, Xianghong Wang, George Loewenstein. 1996. Choosing the wrong pond: Social comparisons in negotiations that reflect a self-serving bias. Quart. J. Econom. CXI(1) 1-19.

Babcock, Linda, George Loewenstein, Samuel Issacharoff, Colin Camerer. 1995. Biased judgments of fairness in bargaining. Amer. Econom. Rev. 85(5) 1337-1343.

Boeri, Tito, Axel Börsch-Supan, Guido Tabellini. 2001. Would you like to shrink the welfare state? A survey of European citizens. Econom. Policy 32 7-50.

Brandel, Franz. 1998. Rabbit: Version 1.0. Mimeo, Institute for Advanced Studies, Vienna, Austria.

Camerer, Colin. 2003. Behavioral Game Theory: Experiments in Strategic Interaction. Princeton University Press, Princeton, NJ.

Camerer, Colin, George Loewenstein. 1993. Information, fairness, and efficiency in bargaining. Barbara A. Mellers, Jonathan Baron, eds. Psychological Perspectives on Justice. Theory and Applications. Cambridge University Press, Cambridge, U.K., 155-179.

Chun, Youngsub, William Thomson. 1992. Bargaining problems with claims. Math. Soc. Sci. 24 19-33.

Corfman, Thomas A., John Schmeltzer. 2002. UAL machinists reject cuts. All other unions OK lower wages. Chicago Tribune. Online edition, (December 28).

Croson, Rachel, Jason Scott Johnston. 2000. Experimental results on bargaining under alternative property rights regimes. J. Law, Econom. Organ. 16(1) 50-73.

Dahl, Gordon B., Michael R. Ransom. 1999. Does where you stand depend on where you sit? Tithing donations and self-serving beliefs. Amer. Econom. Rev. 89(4) 703-727.

Feith, Douglas J. 1993. A mandate for Israel. The National Interest (Fall) 43-58.

Fershtman, Chaim, Daniel J. Seidmann. 1993. Deadline effects and inefficient delay in bargaining with endogenous commitment. J. Econom. Theory 66 306-321.

Franciosi, Robert, Praveen Kujal, Roland Michelitsch, Vernon Smith, Gang Deng. 1995. Fairness: Effect on temporary and equilibrium prices in posted-offer markets. Econom. J. 105 938-950.
Gächter, Simon, Arno Riedl. 2004. Dividing justly in bargaining problems with claims: Normative judgments and actual negotiations. Discussion paper 2004-044/1 Tinbergen Institute, Amsterdam, The Netherlands.

Güth, Werner, Reinhard Tietz. 1985. Strategic power versus distributive justice-An experimental analysis of ultimatum bargaining. Hermann Brandstätter, Erich Kirchler, eds. Economic Psychology. Rudolf Trauner Verlag, Linz, Austria.

Harrison, Glenn, Michael McKee. 1985. Experimental evaluations of the Coase Theorem. J. Law Econom. 28 653-670.

Hennig-Schmidt, Heike. 1999. Bargaining in a Video Experiment. Determinants of Boundedly Rational Behavior. Springer, Berlin, Germany.

Hoffman, Elizabeth, Matthew L. Spitzer. 1985. Entitlements, rights, and fairness: An experimental examination of subjects' concepts of distributive justice. J. Legal Stud. 14 259-279.

Hoffman, Elizabeth, Kevin McCabe, Keith Shachat, Vernon Smith. 1994. Preferences, property rights, and anonymity in bargaining games. Games Econom. Behavior 7 346-380.

Kachelmeier, Steven J., Stephen T. Limberg, Michael S. Schadewald. 1991. A laboratory market examination of the consumer price response to information about producers' cost and profits. Accounting Rev. 66 694-717.

Kahneman, Daniel, Jack Knetsch, Richard Thaler. 1986. Fairness as a constraint on profit seeking: Entitlements in the market. Amer. Econom. Rev. 76(4) 728-741.

Konow, James. 2000. Fair shares: Accountability and cognitive dissonance in allocation decisions. Amer. Econom. Rev. 90(4) 1072-1091.

Konow, James. 2003. Which is the fairest one of all? A positive analysis of justice theories. J. Econom. Lit. XLI(4) 1188-1239.

Kuon, Bettina, Gerald R. Uhlich. 1993. The negotiation agreement area: An experimental analysis of two-person characteristic function games. Group Decision Negotiation 2 323-345.

Loewenstein, George. 2000. Emotions in economic theory and economic behavior. Amer. Econom. Rev. 90(2) 426-432.

Nydegger, Rudy V., Guillermo Owen. 1975. Two person bargaining: An experimental test of the Nash axioms. Internat. J. Game Theory 3 239-249.

O'Neill, Barry. 1982. A problem of rights arbitration from the Talmud. Math. Soc. Sci. 2 345-371.

Romer, Paul M. 1996. Preferences, promises, and the politics of entitlement. Victor Fuchs, ed. Individual and Social ResponsibilityChild Care, Education, Medical Care, and Long-Term Care in America. Chicago University Press, Chicago, IL.

Roth, Alvin E., J. Keith Murnighan. 1982. The role of information in bargaining: An experimental study. Econometrica 50(5) $1123-1142$.

Roth, Alvin E., J. Keith Murnighan, Françoise Schoumaker. 1988. The deadline effect in bargaining: Some experimental evidence. Amer. Econom. Rev. 78(4) 155-162.

Schlicht, Ekkehart. 1998. On Custom in the Economy. Clarendon Press, Oxford, U.K.

Shafir, Eldar, Peter Diamond, Amon Tversky. 1997. Money illusion. Quart. J. Econom. 112 341-374.

Thomson, William. 2003. Axiomatic and game theoretic analysis of bankruptcy and taxation problems: A survey. Math. Soc. Sci. 45 249-297.

Tversky, Amon, Daniel Kahneman. 1974. Judgement under uncertainty: Heuristics and biases. Science 185 1124-1131.

Zajac, Edward E. 1995. Political Economy of Fairness. The MIT Press, Cambridge, MA.

Zuckerman, Miron. 1979. Attribution of success and failure revisited, or: The motivational bias is alive and well in attribution theory. J. Personality 47 245-287.

Zwick, Rami, Xiao-Ping Chen. 1999. What price fairness? A bargaining study. Management Sci. 45(6) 804-823. 